\section{Find out how to please your patients}

For premium, metal-free removable partial dentures (RPDs), offer your patients Ultaire AKP.

This innovative, next generation material was specifically developed by Solvay Dental 360 to bridge the gap between metal and flexible RPDs and to offer patients a biocompatible, lightweight, more aesthetically pleasing alternative.

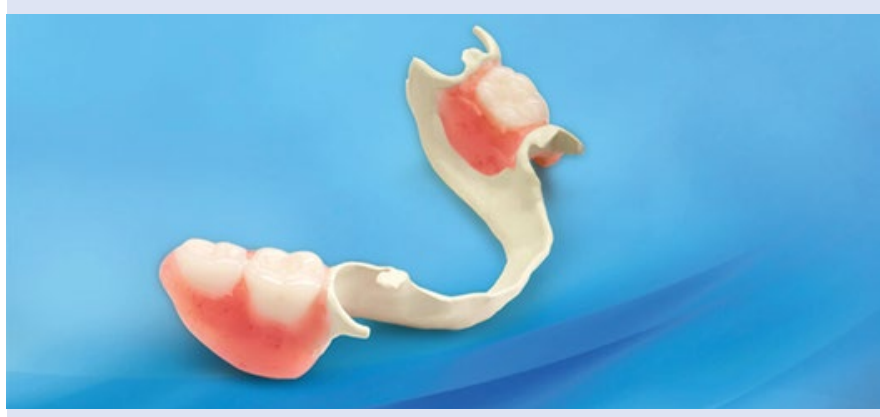

Frames created with Ultaire AKP can be designed in the digital workflow to offer a long lasting, customised fit with superior comfort to improve the overall patient experience.

To find out how to please your patients with Ultaire AKP, arrange a Solvay Dental 360 Professional Lunch and Learn at your practice now.

To book a Solvay Dental 360 Professional Lunch and Learn or to find more information on Ultaire AKP and Dentivera milling discs, visit www.solvaydental360.com.

\section{Combat tooth loss}

Dental implants have become incredibly popular as an effective treatment modality for partial or full edentulism, particularly among elderly patients. TBR's Z1 implant system can provide optimal dental function and aesthetics similar to that of a natural tooth, thanks to proven technology.

\section{Combining}

a highly

biocompatible titanium body with a unique zirconia collar, the $\mathrm{Z} 1$ promotes effective

osseointe-

gration, and

\section{encourages the}

soft tissue to heal around the implant in a way that mimics natural gingival growth. This reduces the risk of iatrogenic inflammation or infection, ensuring a highly satisfactory result.

Help elderly patients combat tooth loss with the $\mathrm{Z} 1$ by contacting Denka today.

For more information on the $\mathrm{Z} 1$ implant, visit tbr.dental, email hello@denkauk.com or call 08007076212.

\section{Exceptional optics and enhanced comfort}

For a variety of cutting-edge dental loupes from leading manufacturer, Carl Zeiss, look no further than Nuview. Practitioners will discover the many benefits of the EyeMag Pro and EyeMag Smart, which both boast exceptional optics and enhanced user comfort.

Both systems deliver outstanding image quality that extends to the peripheral zones, enabling clinicians to recognise and differentiate between even the most minute structures. Customised with the EyeMag Light II for optimal illumination, the EyeMag Pro and the EyeMag Smart represent the best in dental magnification solutions.

Contact Nuview to explore the superior comfort, usability and versatility of the EyeMag Pro and the EyeMag Smart dental loupes.

For more information call Nuview on 01453 872266, email info@nuview-ltd.com or visit www.nuview.co.

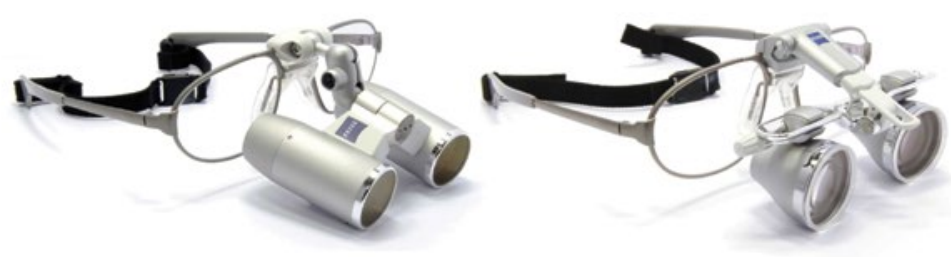

\section{Cancer screening glasses win award}

Goccles oral cancer screening glasses have recently been honoured with the Edison Best New Product Award. Recognising excellence in design and innovation, these awards set apart those products deemed to be 'game changers'. Named after the iconic US inventor Thomas Edison, recipients of the award symbolise ingenuity and creativity.

This is not the first time the product has received an independent third party endorsement as earlier this year Dental Advisor rated Goccles as their preferred product for oral cancer screening. With an enviable rating of $92 \%$ they found the Goccles system easy to use and effective at displaying early lesions.

Goccles oral cancer screening glasses allow the clinician to run a simple, non-invasive and painless test using the technology of fluorescence and cell-tissue autofluorescence by using the wavelengths emitted by curing-lights. This allows the user to see in a clear and accurate way any anomalies of the oral cavity. The basic principle is that the auto-fluorescence of abnormal cells lining the mouth when exposed to light, differs to that seen occurring in normal cells. Goccles glasses allow the clinician to see differences in auto-fluoresence of the tissues, with normal cells appearing green and abnormal cells dark.

Goccles are distributed exclusively through Dental Sky. For more information visit https://www.dentalsky.com/goccles-oralcancer-screening-glasses.html. 